\title{
第14回大会印象記
}

\author{
小畑大吉
}

初めて見る美しい東京の雪景色の中で, 第14回 大会は盛会裏に終了した。樫田会長のご欠席は大 変残念であったが, 日野原会長代行, 川井大会長 以下関係の方々のご努力で大会行事がすべて順調 にすすめられたことは喜ばしかった。

講演は特別講演 2 題, 大会長講演, 教育講演, 外国人招待者講演 3 題, シンポジゥム，指定発言 の他に一般演題 85 願と誠に多彩な内容で参会者も 423名に及んだときいている。

以下私が本大会に参加して得た印象をできるだ け率直に述べょと思うが，一般演題に関しては 2 会場に別れているのでどらしても聴講に偏りが あることを拕びしておきたい。

学会の掉尾を飾ったシンポジウム「ハイテク， ロジーと健診」は大変難しい討議内容であったが 有意義であったと思う。

司会の岩塚先生が冒頭で述べられたところによ ると「世界で初めて米国に AMHTS が誕生した のが1964年で，も520年以上前になる。また我が 国に初めて AMHTS が設置されてからも515年 になる。発足当時としては時代の最先端をゆく技 術が導入されていたが，現在は発足当時には予測 も出来なかったよらなハイテクノロジーの華々し い展開が見られるようになったので，ここで今一 度じっくり研究して私どものシステムの再点検を する時期になった。といらことで，一堂に会し た当代第一級の演者から講演を聴くことになっ た。各演者は期待に違わず含蓄ある巧みな話術で 私どもを魅了した。しかし内容が極めて複雑で高 度なものであっただけに会員はいささか消化不良

\section{Inpression of 14 th general meeting society of JMHTS}

大手前病院 健康管理センター
を起こした気配もなしとしないように思われた。 願わくは，今後も教育講演のような形で繰り返し て取り上げて頂ければ，やがて会員の血となり肉 となって効果を挙げるのではないかというのが率 直な感想であった。ともあれ本シンポジウムは, その豪華な幕開けとして充分意義があったよらに お子ら。

島薗安雄先生の特別講演「中高年者の精神保健 の諸問題」は私どもにとって誠に有り難い講演で あった。現在我が国の 患者統計で精神障害は高 血圧性疾患に次いで高い受療率を呈しており， Primary Health Care の最前線にいる私どもの受 診者の中にも睡眠障害を伴ららつ病を思わせる症 例や，仮面うつ病と思われる症例に遭遇すること も稀でないからである。

特別講演の他の一題は常岡健二先生による「消 化性潰瘍一最近の内科的治療」であった。消化性 潰瘍は日常の受診者の中で発見されるのは数\%に 及び, 高血圧症, 糖代謝異常などに次いで多く, せっかく発見して治療しても再発することが多 い。それは有名なフレーズ〔Once an Ulcer, Always an Ulcer] に示されている如くで, この再 発防止は潰瘍症治療上の重要課題である。潰瘍治 癒の促進や再発防止についてもいろいろ学ぶこと ができた。

川井博大会長講演は「尿所見の臨床」と題され ていて, 日常の健診で最もポピュラーで且つ基本 的な所見である顕微鏡的血尿という所見から，ど のような病気が，どのような特徵をもって診断出 来るのかといら内容は丈変興味深かったこの泌尿 器科のテーマは, 遡れば第12回本大会での同じく 川井先生による教育講演「下部尿路悪性腫瘍の健 診上の問題点」から第13回本大会における甲斐祥 
生先生による教育講演「血尿の病因診断」, 更に本 大会での日台英雄先生による特別講演「中高齢者 にみられる腎機能障碍の臨床」へとつながってゆ く。日台先生の特別講演の司会を勤められた川井 大会長が，その挨拶の中で「腎不全は総ての成人 病の最後にゆきつくところである」と言われたの は誠に味わい深い言葉であった。

清瀬闊先生による指定発言「耐糖能検討小委員 会報告」は，ここ数年間に亘るご苦労の集大成で あり，本学会に対する最終答申として発表され た。これによって胃透視後糖飲といら変則的な形 をとらずに空腹時血糖, $\mathrm{Hb} \mathrm{A} 1 \mathrm{C}$ 等から耐糖能の スクリーニングを行い得るとの結論になったわけ で, 後は各施設で, それぞれの状況を勘案してこ の方式をとりいれてゆくことになるものと思われ る。

今一つ本大会の特徵となったのは韓国, 台湾な ど近隣アジア諸国からの初めての招待講演が聴け たといらことで，結核，寄生虫病等がなお高頻度 に発見されるといら発表には一昔前の我々の姿を 思い出させるよらで一種の懐かしさを和ぼえた が，そんな中で第一次予防としての栄養改善に取 り組む進取的な姿勢が注目された。

以上が，順序が前後したが，私の目でみた本大 会のメイン・イベントであった。

一般課題も85題と例年より多かったが， 2 会場 に別れていたため，聴きたい演頭を追って第一会 場と第二会場との間をマラソンのようにかけ回っ
たこともあった。

指導やフォローアップなど MHTS の S に該 当する業務は, きわめて大切だと頭では理解して いても, 実際には $\mathrm{S} よ り も \mathrm{~T}$ 即ち検査・診断を優 先してしまわざるを得ない現状であるが，そんな 中で本大会では $\mathrm{S}$ に当たる業務の報告が扔扔かっ た。残念乍ら私は別会場での自分の出番と重なっ てとの多くを聴くことが出来なかったが，ソルト ペーパーを用いた減塩食の指導や, 運動量の調査 データーの報告は本大会になって初めて聴けた発 表で興味深かった。

血液疾患の報告が 2 題みられたが，いずれもご 苦労のあとが伺える立派な報告であった。この種 の報告も今までの当学会に欠けていた分野ではな いかと思う。白血球増多症のフォローアップ, 頸 部等の腫瘤の視診, 触診が診断のきっかけとなる 悪性リンパ腫, 甲状腺腫瘍等の報告も, もっとあ っても良いのではないかとおもわれた。

大会第 2 日目, 昼食後の恒例の総会の最後には 次回 [第15回]大会長の鈴木啓吾先生が次回大会 への参加を呼びかけて示された秀麗富士のスライ ドが誠に美しかったのが強く印象に残った。

最後に日本総合健診医学会第14回大会の成功を 祝らとともに川井博大会長, 森本和良準備委員長 の両先生を初め関係の皆様方のご苦労を深謝する と共に, 第15回静岡大会での元気な再会を願って 私の印象記としたい。 